\title{
BERGSON NOS FALA DE CINEMA ${ }^{1}$
}

A morada do filósofo encontrava-se toda florida. Apoiado sobre um console, o Sr. Bergson sorria entre um buquê de lilases e um tacho de orquídeas, homenagem dos estudantes, contentes com a eleição do mestre para a Academia.

"Imagine só," disse o filósofo de súbito, "que uma casa de filmes me pediu para posar."

Bergson: casaca preta leve, mangas dobradas, colarinho falso. Das mangas saltam mãos esguias, nervosas, febris; do colarinho falso, um pequeno rosto de bochechas rosadas, a fronte contorna suavemente a curva do crânio; bigodes loiros feitos ao nível dos lábios. Dois olhos azuis "absortos" parecem clarear o interior de seu crânio, cobertos por sobrancelhas muito mais espessas que os bigodes. Seu rosto articula-se vivamente do colarinho falso. Quando o Sr. Bergson fala, inclina-se num gesto natural à reflexão. A voz um pouco hesitante, um pouco longínqua, concorre para o aspecto delicadamente "hoffmanesco" do filósofo, em seu casarão branco, de amplos salões, perdido no meio de um jardim de Auteuil.

"Não aceitei," prosseguiu o Sr. Bergson, "se bem que o cinematógrafo me interesse, assim como toda nova invenção. O filósofo deve levar em conta os acontecimentos da vida exterior. Tudo que eu trouxe de novo à filosofia até hoje teve por base a experiência. Ao escrever meu livro Matéria e Memória, estudei durante cinco anos centenas de casos de perda de memória, interrogando os afásicos; antes de empreender A Evolução Criadora, consagrei dez anos à biologia. Nada deve deixar o filósofo indiferente. Assisti uma vez ao cinematógrafo... mas já há alguns anos. Foi em suas origens. É evidente que esta invenção, complemento da fotografia instantânea, pode sugerir novas ideias ao filósofo. Poderia ajudar com a síntese da memória ou mesmo do pensamento. Se a circunferência é composta de uma série de pontos, a memória é, assim como o cinematógrafo, uma série de imagens. Imóveis, estão em estado neutro; em movimento, eis a vida. E alguém poderia concluir, ou já deve ter concluído, que: a vida, é movimento. A essência da luz, do som, não é apenas a vibração? O olho vivo não seria apenas um cinematógrafo? Esta suposição poderia ser confirmada pela

1 Texto em domínio público. Publicação original e republicações, ver Referências. Traduzido por José Paulo Maldonado de Souza. Mestre em Filosofia pela Universidade Federal de Pernambuco (UFPE). E-mail: josepaulomaldonado@gmail.com.

2 Relativo a E.T.A. Hoffmann (1776 -1822), autor do conto O Homem de Areia (Der Sandmann) entre outros . N.T. 
seguinte constatação: o cinematógrafo é capaz de conduzir de volta os pintores ao verdadeiro caminho. Sabes da revolução causada em pintura pela invenção da fotografia instantânea. Depois desta descoberta, os artistas perceberam que muitas vezes os flagrantes ${ }^{3}$, por exemplo, de cavalos de corrida, como eles os representavam, não estavam exatos. E os retificaram. Sucede-se que: inspirando-se nos flagrantes surpresas da fotografia instantânea, os artistas não foram capazes senão de criar figuras, no mais das vezes, congeladas, sem vida. A exatidão matemática venceu, certo. Mas a impressão de verdade se perdeu. O cinema aprendeu com a pintura que a fotografia estava errada. Ao reproduzir o movimento partindo de sua impressão pessoal, o artista o recompõe fundindo num só diversos flagrantes sucessivos, dando a ilusão de vida e, portanto, de movimento. Estes flagrantes, ele os reencontra sobre a tela.

"Dessa maneira, em páginas admiráveis, o Sr. Rodin ${ }^{4}$ explica como se dá vida a uma escultura: fundindo as fases de um movimento nas diferentes partes da figura modelada.

"Meu colega no Collège de France, o Sr. François Franck ${ }^{5}$, pôde mostrar aos seus alunos, graças à fotografia instantânea e auxílio do cinematógrafo, as fases da duplicação de uma célula.

"Não assisti senão à "naturais" ao cinematógrafo. Mas estou convencido de que os atores encarregados de desempenhar diante da objetiva aperfeiçoarão a arte da mímica, e o teatro se beneficiará; pois a mímica é uma arte importante, relativamente à arte teatral.

"Mas o cinematógrafo será acima de tudo um documento inestimável para nossos sucessores, se as fitas não se deteriorarem ${ }^{6}$. Devemos fazer uma ideia completamente falsa dos “antigos em movimento". Quanto prazer sentiríamos vendo senão Cleópatra, ao menos Napoleão passando sobre a tela. Assim, já podemos assistir aos acontecimentos contemporâneos sem correria, sem perigo, sentados numa poltrona. Sei que as imagens passam na tela mais depressa que na vida real. É do princípio mesmo do cinematógrafo. Mas nossa imaginação pode facilmente lentear o movimento.

"Para concluir, se o cinematógrafo diverte o vulgo, auxilia e auxiliará seriamente o sábio, o artista, o historiador, e inclusive o filósofo. Mas este não pode realmente forçar o

3 Observando o uso da "cena muda" brasileira: attitude foi traduzida por flagrante; objetiff por objetiva; scénes por naturais; jouer por desempenhar; films por fitas. A opção por "naturais" remete ao vocabulário em que se opõem "fitas naturaes" (sic) e "fitas de enrêdo" (sic). Nas origens do cinematógrafo os "naturais" muitas vezes não passavam de sequências, sem a estruturação narrativa dos documentários modernos, donde scénes. Cf. Revista Scena Muda (1921-1955) e A Imagem Autônoma: ensaio de teoria do cinema (1972), de Evaldo Coutinho. N.T.

4 Auguste Rodin (1840-1917), consagrado escultor francês, autor entre outras da famosa escultura "O Pensador". N. T.

5 François Franck (1849-1921), fisiólogo francês, professor do Collège de France, considerado pioneiro no uso do cinematógrafo com propósitos científicos e didáticos. N.T.

6 Bergson alude ao fato de que as películas deterioram-se, sendo inclusive sujeitas à combustão espontânea. N.T. 
próprio reconhecimento servindo-se ele mesmo de tema... apesar da amabilidade com que inicialmente tenha sido feita a proposta."

\section{REFERÊNCIAS BIBLIOGRÁFICAS:}

\section{Publicado originalmente:}

BERGSON, H. Henri Bergson nous parle de cinéma. Le Journal, Paris, p. 7, 20 fev. 1914. Entrevista por Michel Georges-Michel.

\section{Republicado em francês:}

Henri Bergson nous parle de cinéma. Positif, Paris, v. 404, p. 56-57, 1994.

\section{Publicado em inglês:}

Henri Bergson talks to us about cinema. Cinema Journal, Texas, v. 50, n. 3, p. 79-82, 2011. Traduzido por Louis-Georges Schwartz. 